\title{
Study on quality characteristics of fish paste containing Curcuma aromatica powder
}

\author{
Bock-Hee Park ${ }^{1}$, Yu-Jin Jung ${ }^{1}$, Hee-Sook Cho ${ }^{2 *}$ \\ ${ }^{1}$ Department of Food and Nutrition, Mokpo National University, Muan 534-729, Korea \\ ${ }^{2}$ Department of Culinary Art, Chodang University, Muan 534-701, Korea
}

\section{강황 분말을 첨가한 어묵의 품질 특성 연구}

\author{
박복희 ${ }^{1} \cdot{\text { 정 } \text { 유진 }^{1} \cdot \text { 조희숙 }}^{2 *}$ \\ ${ }^{1}$ 목포대학교 식품영양학과, ${ }^{2}$ 초당대학교 조리과학부
}

\begin{abstract}
This study was conducted to promote the utilization of fish paste with $0,2,3$, and $4 \%$ added Curcuma aromatica powder. The moisture, crude protein, crude lipid, and crude ash contents of the used Curcuma aromatica powder were $11.15,6.25,2.36$, and $9.98 \%$, respectively. For the Hunter color values, the $L$, a values of the fish paste decreased with increasing concentrations of Curcuma aromatica powder, while the b values appreciated. In the folding test, whose results reveal the flexibility of the fish paste, all the test samples showed AA results. In the texture meter test, the hardness, cohesiveness, and springiness increased with increasing concentrations of Curcuma aromatica powder, but the gumminess and brittleness of the fish paste were reduced. In the sensory evaluation, the color and taste of the fish paste with $3 \%$ added Curcuma aromatica powder were preferred over those of the other fish pastes. These results suggest that Curcuma aromatica powder can be applied to fish paste to achieve high quality and functionality.
\end{abstract}

Key words : fish paste, Curcuma aromatica powder, quality characteristics

\section{서 론}

어묵은 일반적으로 다른 동물성 단백질 식품에 비해 가 격이 저렴하며 서민들이 많이 애용하는 식품으로, 형태 및 재료에 따라 다양한 종류의 제품들이 시판되고 있다. 어묵 은 어육의 염용성 단백질을 용출시킨 고기풀에 부재료를 혼합하여 찌거나, 삶거나, 식용유에 튀긴 것 또는 이를 건조 한 것으로 찐 어묵, 삶은 어묵, 구운 어묵, 튀긴 어묵 또는 건조 어묵을 말한다(1). 이러한 어묵의 품질 결정요인은 색택, 향미, 탄력에 의하여 결정되며, 그 중에서 탄력이 품질

*Corresponding author. E-mail : hscho61@hanmail.net Phone : 82-61-450-1645, Fax : 82-61-450-1641

Received 15 December 2014; Revised 14 January 2015; Accepted 23 January 2015.

Copyright (c) The Korean Society of Food Preservation. All rights reserved.
을 결정하는 주요 인자가 된다. 탄력에 영향을 미치는 요인 으로는 원료의 선도와 어종, 첨가물의 종류 및 사용량, 가열 방법, 그리고 첨가되는 수분함량 등이 있다(2). 특히 어묵은 단백질과 칼슘이 풍부하며, 저칼로리, 저지방의 식품으로 서 기호도가 매우 높아 최근 다양한 소비자의 기호에 맞춰 다양한 기능성 어묵이 개발되고 있는 실정이다. 대중화된 어묵의 다양화 및 고품질화를 위하여 멸치(1), 단백질(3), 오징어(4), 우렁쉥이 껍질(5), 미더덕(6), 마 분말(7), 고추냉 이(8), 홍어(9), 새우(10), 복어(11). 파래(12) 등을 첨가하여 기능성과 기호성을 증진시키려는 연구들이 계속적으로 수 행되고 있다. 어묵은 단백질과 칼슘이 풍부하며, 저칼로리, 저지방의 식품으로서 기호도가 높아 최근 다양한 소비자의 기호에 맞춰 기능성 식품으로 개발 가능성이 매우 높다.

강황(Curcuma aromatica)은 열대 아시아 특히 인도가 원 산지로 열대 지방 및 중국의 남부지방에 자생 또는 재배하 는 다년생 초본으로, 꽃 이삭은 잎보다 먼저 나오고 넓은 
달갈 모양이며 연한 녹색의 포에 싸여 있다. 4 6월에 잎겨 드랑이에서 노란 꽃이 피며, 윗부분의 포는 나비가 약간 좁고 끝은 담자홍색이며 잎겨드랑이에 꽃이 달리지 않으며 뿌리줄기의 겉은 연한 노란색이고, 속은 주홍빛으로 장뇌 같은 향기가 난다(13). 강황의 성분은 향기성분과 커큐미노 이드(curcuminoid)의 색소성분으로 나누는데, 향기 성분 보 다는 커큐미노이드에 의한 착색효과가 중요한 것으로 평가 되어 오고 있다. 강황의 성분들은 간장의 해독 촉진과 담즙 의 분비작용 및 어혈작용이 뛰어난 것으로 알려져 있으며 (14), 최근 강황의 생리활성 물질인 curcuminoid의 약리 효 과가 알려지면서 의학 분야를 중심으로 간장염, 담도염, 담석증, 카타르성 황달, 소화기 및 심혈관계에 대한 작용, 항 혈소판 응집, 혈중 지질 강하, 항산화, 항돌연변이, 항종 양, 항균 작용 등에 대한 연구에 활발히 이용되고 있다 (15-18). 강황을 식품에 적용한 연구로는 강황추출물이 쌀 밥의 저장성에 미치는 영향(19), 강황 첨가 두부의 이화학적 품질특성(20), 강황두부 및 스테이크의 품질특성 $(21,22)$, 강 황파우더를 첨가한 초콜릿의 특성(23), 강황분말 첨가 소시 지의 제조조건 최적화(24), 강황 첨가 만두피의 품질특성 (25) 등이 있다.

본 연구에서는 강황을 첨가한 새로운 어묵을 개발하고자 강황 분말 첨가량의 농도를 달리하여 어묵을 제조한 후, 품질 특성을 평가함으로써 강황 분말의 기능성 식품소재로 서의 가능성과 고품질 강황 어묵의 제품 개발을 위한 기초 자료를 제공하고자 하였다.

\section{재료 및 방법}

재 료

본 실험에 사용된 시료용 연육은 수입된 냉동 돔연육(베 트남산, 1 등급)을 대림 식품에서 제공받아 이용하였다. 강 황 분말은 인터넷을 통하여 전남 진도군 강황영농조합법인 특산물 쇼핑몰에서 구입하였으며, 소맥분은 중력분(1등급, 제일제당)을 이용하였으며, 식용유는 옥수수씨눈 $100 \%$ (백 설), MSG(L-글루탐산나트륨), 설탕(제일제당), 천일염(신 안토판염) 등을 사용하였다.

\section{강황 어묵의 배합비 및 제조 방법}

강황 분말 함유 어묵은 Table 1 의 배합비에 따라 제조하 였다. 냉동 보관된 연육은 혼합기(Kitchen Aid K5SS, Hobart, USA)를 이용하여 1단계에서 세절과 혼합을 하였으 며 그 후 5 단계로 속도를 높여 혼합하였다. 냉동 연육을 세절하면서 5 분 간격으로 천일염, 강황 분말을 각각 0,2 , 3 및 4\%씩 첨가하면서(예비실험에서 $5 \%$ 이상에서는 기호 도가 아주 낮음), 소백분, 식용유 MSG, 설탕(제일제당) 등 을 함께 배합비에 따라 차례로 넣고 25 분간 혼합하였다.
혼합 후, 길이 $9 \mathrm{~cm}$, 너비 $2.5 \mathrm{~cm}$, 높이 $1 \mathrm{~cm}$ 로 성형한 후 $170^{\circ} \mathrm{C}$ 의 기름에서 3 분 20 초간 튀겨 어묵을 제조하였으 며 실험은 3회 반복 실시하였다(26).

Table 1. Formula for the manufacturing of fish paste containing Curcuma aromatica powder

$(\%)$

\begin{tabular}{lcccc}
\hline \multicolumn{1}{c}{ Material } & Control & $2 \mathrm{CAP}^{1)}$ & $3 \mathrm{CAP}$ & 4 CAP \\
\hline Fish paste & 65 & 65 & 65 & 65 \\
Curcuma aromatica powder & 0 & 2 & 3 & 4 \\
Wheat flour & 18 & 16 & 15 & 14 \\
Soybean oil & 2 & 2 & 2 & 2 \\
Sugar & 1.13 & 1.13 & 1.13 & 1.13 \\
Salt & 1 & 1 & 1 & 1 \\
Water & 12.47 & 12.47 & 12.47 & 12.47 \\
MSG & 0.4 & 0.4 & 0.4 & 0.4 \\
\hline \multicolumn{1}{c}{ Total } & 100.00 & 100.00 & 100.00 & 100.00 \\
\hline
\end{tabular}

${ }^{13}$ Each numbers in front of Curcuma aromatica powder mean the added amount \% of Curcuma aromatica powder in fish paste.

\section{일반성분 분석}

강황 분말의 일반 성분은 $\mathrm{AOAC}$ 법(27)으로 측정하였다. 수분 함량은 $105^{\circ} \mathrm{C}$ 상압가열건조법, 회분은 $550^{\circ} \mathrm{C}$ 전기로 를 이용한 직접 회화법, 조지방은 Soxhlet 추출법으로 측정 하였고 조단백질은 단백질 자동분석기(Kjeltec 2200 Auto Analyzer, Tecator Co., Gothenburg, Sweden)을 이용하여 micro- Kjeldahl법으로 분석하였다. 탄수화물은 시료 전체 무게(\%)에서 수분, 회분, 조지방, 조단백질을 뺀 나머지 값 을 \%로 표시하였다.

\section{강황 어묵의 색도 측정}

어묵의 색도는 색차계(Chromameter CR-200, Minolta, Camera Co., Japan)를 사용하여 Hunter's L(명도, lightness), $\mathrm{a}$ (적색도, redness), $\mathrm{b}$ (황색도, yellowness)값을 3회 반복 측 정, 그 평균값으로 나타내었다. 이때 표준 백판의 L값 97.91 , $\mathrm{a}$ 값 $-0.03, \mathrm{~b}$ 값 1.42 를 기준으로 실시하였다.

\section{강황 어묵의 절곡검사}

길이 $9 \mathrm{~cm}$, 너비 $2.5 \mathrm{~cm}$, 높이 $1 \mathrm{~cm}$ 의 어묵 시료를 3 $\mathrm{mm}$ 두께로 잘라, 이것을 접었을 때의 파열 상태의 정도로 써 절곡검사를 실시하였다. 즉, 네 겹으로 접어서 균열이 생기지 않으면 $\mathrm{AA}$, 두 겹으로 접어서 균열이 생기지 않으면 $\mathrm{A}$, 네 겹으로 접어서 $1 / 2$ 이하로 균열이 생기면 $\mathrm{B}$, 두 겹으로 접어서 전체에 균열이 생기면 $\mathrm{C}$, 두 겹으로 접어서 두 조각 으로 되면 $\mathrm{D}$ 로 표시하였다(28). 
강황 어묵의 조직감 측정

어묵의 조직감은 rheometer(Sun compact 100, Sun Scientific, Tokyo, Japan)를 이용하여 hardness, cohesiveness, springiness, gumminess 및 brittleness를 3회 반복 측정하여 평균값으로 나타내었으며, 이 때 rheometer의 측정조건은 Table 2와 같 다. 측정치 시료의 크기는 직경 $30 \mathrm{~mm}$ 의 round형으로 같은 시료를 두 번 누를 때 얻어지는 texture meter curve를 분석하 여 texture 측정치를 계산하였다.

Table 2. Measurement conditions for the rheometer

\begin{tabular}{lc}
\hline \multicolumn{1}{c}{ Test type } & Mastication \\
\hline Sample depth & $10.00 \mathrm{~mm}$ \\
Adapter area & $10.00 \mathrm{~mm}$ \\
Load cell & $2.00 \mathrm{~kg}$ \\
Table speed & $60.00 \mathrm{~mm} / \mathrm{min}$ \\
\hline
\end{tabular}

강황 어묵의 관능검사

시료는 일정한 크기 $(9 \mathrm{~cm} \times 2.5 \mathrm{~cm} \times 1 \mathrm{~cm})$ 로 잘라 오후 2 시에서 3 시 사이에 관능검사를 실시하였다. 어묵에 대한 관능검사는 잘 숙련된 관능검사 연구원인 목포대학교 대학 생 20명을 검사방법과 평가특성을 교육시킨 후 실시하였 다. 어묵은 흰 접시에 담아 제공하였으며 한 개의 시료를 평가 한 후 반드시 생수로 입안을 두 번 헹구도록 하였고, $1 \sim 2$ 분 지난 후에 다른 시료를 시식한 후 평가를 하도록 하였다. 측정 항목은 texture, flavor, color, taste, overall acceptance 등이었으며, 최고 5점, 최하 1점(5점 채점법)으 로 표시하도록 하였다(29).

\section{통계처리}

어묵의 실험결과는 SPSS(Statistics Package for the Social Science, 14.0 for Window) package를 이용하여 ANOVA를 실시하였으며 유의적인 차이가 있으면 다중범위검정 (Duncan's multiple range test)을 실시하여 집단 간의 유의성 $(\mathrm{p}<0.05)$ 을 검증하였다.

\section{결과 및 고찰}

\section{일반 성분}

실험에 사용한 강황 분말의 일반 성분을 분석한 결과, 수분 함량은 $11.15 \%$, 조단백질 함량은 $6.25 \%$, 조지방 함량 은 $2.36 \%$, 조회분 함량은 $9.98 \%$, 탄수화물은 $70.26 \%$ 의 조성 을 나타냈다. 강황 분말로 만두피를 제조한 Park 등(25) 연구에서는 강황 분말의 수분함량 $10.16 \%$, 단백질 함량 $6.20 \%$, 지방 함량 $1.36 \%$, 회분 함량은 $9.96 \%$ 의 조성을 보여 비슷한 경향을 보였다. 강황 분말을 첨가한 초콜릿 연구에 서는 강황 분말의 수분함량 $20.0 \%$, 단백질 함량 $5.62 \%$, 지
방 함량 $2.91 \%$, 회분 함량 $7.29 \%$ 로 나타났다(24). 한편 강황 분말로 쿠키를 제조한 Choi 등(30)의 연구에서는 강황 분말 의 수분함량 $12.8 \%$, 단백질 함량 $1.9 \%$, 지방 함량 $1.0 \%$, 회분 함량은 $1.2 \%$ 의 조성을 보였다. 이는 강황의 채취시기 에 따라 일반성분의 조성의 차이가 있는 것으로 사료된다 (31).

\section{강황 어묵의 색도와 절곡검사}

강황 분말을 각각 $0,2,3$ 및 $4 \%$ 를 첨가하여 제조한 어묵 의 색도와 절곡검사 측정 결과는 Table 3 과 같다. 명도 (lightness)를 나타내는 L값은 대조군이 64.35로 가장 높았 고 강황 분말 $4 \%$ 첨가군이 54.45 으로 가장 낮아 강황 분말 첨가량이 증가할수록 $\mathrm{L}$ 값은 유의적으로 낮아져 색이 어두 워지는 경향을 보였는데, 이는 강황 첨가 두부(20), 강황 첨가 쿠키(28)의 품질 연구에서 $\mathrm{L}$ 값이 유의적으로 낮아졌 다는 결과와 일치하였다. 적색도(redness)를 나타내는 a값 은 대조군이 -3.35 로 가장 낮았고 $4 \%$ 첨가군이 0.09 로 가장 높았으며, 강황 분말 첨가량이 증가할수록 높아졌다. 또한 대조군, $2,3 \%$ 첨가 만두피는 음(-)을 나타내어 녹색의 경향 을 보였다. 이는 강황 분말을 첨가한 쿠키(30)의 연구와 유사한 경향을 보여 부재료의 색에 영향을 받는 것으로 생각된다. 황색도(yellowness)를 나타내는 $\mathrm{b}$ 값은 강황 분말 이 첨가된 어묵이 대조군보다 더 높게 나타났으며, 강황 분말의 첨가량이 많아질수록 증가하는 경향을 보였다 $(\mathrm{p}<0.05)$. 이러한 결과는 강황 스테이크(22) 및 강황 파우더 를 첨가한 기능성 초콜릿(23)에서도 강황 분말 첨가량이 증가함에 따라 황색도(b값)가 높아지는 것으로 나타나 본 연구와 비슷한 경향을 보였으며, 이는 강황 분말이 황색을 나타내기 때문이라고 생각된다. 한편, 강황 분말 첨가로 인해 밀가루가 상대적으로 줄어들게 되어 전분의 감소에 따른 영향이 클 것으로 생각했는데, 강황을 첨가하지 않는 어묵(대조군)과 강황을 첨가한 어묵의 수분 함량은 강황 분말의 첨가 여부 및 첨가 비율에 관계없이 대조군, $1 \%$, $2 \%, 3 \%$ 및 $4 \%$ 첨가 어묵이 각각 $70.13,70.21,70.52,70.30$, $70.41 \%$ 로 모든 어묵이 $70 \%$ 대의 수분을 함유하고 있어 비 교적 고른 수분 함유 양상을 보이고 있었다. 따라서 배합비 의 변화에 따른 영향을 받지 않는 것으로 판단된다. Lanier 와 $\operatorname{Lee}(32)$ 는 게맛살과 같이 백색을 요구하는 제품에는 칼 슘제를 첨가하는 것이 백색 개선 효과가 있다고 하였으며, Choi와 $\mathrm{Kim}(33)$ 은 칼슘제의 첨가 농도가 증가할수록 어묵 의 백색 개선 효과가 높아지는 경향을 타나내었다고 보고하 였다. 이로 보아, 강황 분말을 첨가할수록 명도가 낮아진 강황 어묵의 백색 개선 효과를 위해서는 어묵 제조시에 칼슘제를 첨가하는 방법을 고려해 볼 수 있을 것으로 사료 된다. 어묵의 유연성과 탄력성을 나타내는 절곡검사의 결 과로는 모든 시료에서 $\mathrm{AA}$ 로 측정되어 강황 분말의 첨가에 관계없이 우수한 것으로 평가되었다. 이는 선행 연구에서 
고추냉이, 홍어, 새우, 복어, 파래 및 구기자 분말을 첨가했 을 때와 같은 결과로 나타났다 $(8-12,34)$.

Table 3. Hunter color values of the fish paste samples containing different concentrations of Curcuma aromatica powder, and results of the folding test

\begin{tabular}{ccccc}
\hline $\begin{array}{c}\text { Hunter } \\
\text { color value }\end{array}$ & Control & $2 \mathrm{CAP}^{1)}$ & $3 \mathrm{CAP}$ & 4 CAP \\
\hline $\mathrm{L}$ & $64.35 \pm 1.30^{\mathrm{a} 2)}$ & $59.89 \pm 1.21^{\mathrm{b}}$ & $56.06 \pm 1.15^{\mathrm{c}}$ & $54.45 \pm 1.23^{\mathrm{d}}$ \\
$\mathrm{a}$ & $-3.35 \pm 0.12^{\mathrm{d}}$ & $-2.60 \pm 0.15^{\mathrm{c}}$ & $-1.52 \pm 0.14^{\mathrm{b}}$ & $0.09 \pm 1.16^{\mathrm{a}}$ \\
$\mathrm{b}$ & $15.27 \pm 0.05^{\mathrm{d}}$ & $23.95 \pm 0.10^{\mathrm{c}}$ & $28.04 \pm 1.05^{\mathrm{b}}$ & $30.88 \pm 1.11^{\mathrm{a}}$ \\
\hline Folding test $^{3)}$ & $\mathrm{AA}$ & $\mathrm{AA}$ & $\mathrm{AA}$ & AA \\
\hline
\end{tabular}

${ }^{1}$ Refer to the legend in Table 1.

${ }^{2)}$ Values are mean $\pm \mathrm{SD}$, different superscripts within a row (a-d) indicate significant different at $\mathrm{p}<0.05$.

${ }^{3}$ In folding test, $\mathrm{AA}$ means there was not any crack when folded with 4 folds of fish paste.

\section{강황 어묵의 조직감}

어묵은 첨가 재료 및 제조방법에 따라 다양한 종류로 제조될 수 있으며, 원료 어육의 성상, 어묵의 제조조건, 망상 구조의 형성조건, 부원료 등이 어묵의 탄력에 영향을 미친 다(35). 강황 분말을 첨가한 어묵의 texture 측정 결과는 Table 4에 나타난 바와 같다. 강황 분말의 첨가량이 증가할 수록 강황 어묵의 경도는 증가하는 경향을 나타냈다. 경도 (hardness)는 식품의 단단함을 나타내는 지표로 물질을 변 형시킬 때 필요한 힘을 의미한다(12). 본 연구에서 경도 (hardness)는 대조군이 $110.15 \mathrm{~g} / \mathrm{cm}^{2}$ 로 가장 낮았고 강황 분말 첨가량이 증가할수록 어묵의 경도가 증가하는 경향을 보였으며, $4 \%$ 첨가군이 $141.12 \mathrm{~g} / \mathrm{cm}^{2}$ 로 가장 높아 시료 간의 유의적인 차이를 보였다(p<0.05). Cho와 $\mathrm{Kim}(12)$ 은 파래 분말을 첨가한 어묵의 경우 경도가 높게 나타났는데, 이는 파래 분말에 다량 함유된 섬유소로 인해 어묵의 경도 가 높아진다고 보고하였다. 응집성(cohesiveness)은 대조군 이 $75.52 \%$ 로 가장 낮았으며, 강황 분말 첨가량이 증가할수 록 높게 나타났다. 우렁쉥이로부터 추출한 섬유소를 첨가 한 어묵(5)의 경우에 섬유소의 첨가량이 증가할수록 응집성

Table 4. Texture profile analysis of the fish paste samples containing different concentrations of Curcuma aromatica powder

\begin{tabular}{lcccc}
\hline \multicolumn{1}{c}{ Properties } & Control & $2 \mathrm{CAP}^{\mathrm{l}}$ & $3 \mathrm{CAP}$ & 4 CAP \\
\hline Hardness $\left(\mathrm{g} / \mathrm{cm}^{2}\right)$ & $110.15 \pm 9.25^{\mathrm{d}}$ & $129.20 \pm 9.30^{\mathrm{c}}$ & $135.41 \pm 9.15^{\mathrm{b}}$ & $141.12 \pm 10.20^{\mathrm{a} 2}$ \\
Cohesiveness(\%) & $75.52 \pm 1.10^{\mathrm{d}}$ & $79.12 \pm 1.15^{\mathrm{c}}$ & $86.45 \pm 1.50^{\mathrm{b}}$ & $89.85 \pm 1.62^{\mathrm{a}}$ \\
Springiness $(\%)$ & $93.10 \pm 1.10^{\mathrm{d}}$ & $95.97 \pm 1.15^{\mathrm{c}}$ & $98.45 \pm 1.50^{\mathrm{b}}$ & $101.85 \pm 1.62^{\mathrm{a}}$ \\
Gumminess(g) & $531.15 \pm 1.30^{\mathrm{a}}$ & $528.62 \pm 1.22^{\mathrm{b}}$ & $512.21 \pm 1.20^{\mathrm{c}}$ & $500.22 \pm 1.13^{\mathrm{d}}$ \\
Brittleness $(\mathrm{g})$ & $494.21 \pm 2.02^{\mathrm{d}}$ & $428.10 \pm 1.55^{\mathrm{c}}$ & $387.12 \pm 1.21^{\mathrm{b}}$ & $350.85 \pm 1.15^{\mathrm{a}}$ \\
\hline
\end{tabular}

${ }^{1)}$ Refer to the legend in Table 1 .

${ }^{2)}$ Values are mean $\pm S D$, different superscripts within a row (a-d) indicate significant different at $\mathrm{p}<0.05$.
이 감소하였다고 보고된 바 있어서, 본 결과와는 차이를 보였다.

탄력성(springiness)은 대조군이 $93.10 \%$ 로 가장 낮았으 며, 강황 분말 첨가군은 95.97 101.85\%로 높게 나타나 강 황 분말 첨가량이 증가될수록 탄력성이 증가되는 것으로 나타났다. 검성(gumminess)은 대조군이 $531.15 \mathrm{~g}$ 으로 가장 높았으며 강황 분말 첨가량이 증가될수록 감소하여 $4 \%$ 첨가군이 $500.22 \mathrm{~g}$ 으로 가장 낮아 시료간에 유의적인 차이 가 있었다. 파쇄성(brittleness)은 대조군이 $494.21 \mathrm{~g}$ 으로 가 장 높았으며, 강황 분말 $4 \%$ 첨가군이 $350.85 \mathrm{~g}$ 으로 낮게 나타나 시료 간의 유의적인 차이를 보여 $(\mathrm{p}<0.05)$, 강황 어묵 은 강황 분말의 첨가량이 증가될수록 검성과 파쇄성이 감소 하는 것을 확인할 수 있었다. Seo와 Cho(10)의 새우 어묵, Cho와 $\operatorname{Kim}(12)$ 의 파래 어묵, Shin 등(34)의 구기자 어묵, Shin과 Park(36)의 뽕잎 어묵의 경우, 부재료의 첨가량이 증가할수록 검성(gumminess)과 파쇄성(brittleness)이 감소 한 것으로 나타나 본 결과와 비슷하였다. 그러나 홍어 분말 을 첨가한 어묵(9)의 경우에는 홍어 분말의 첨가량이 증가 할수록 검성 및 파쇄성이 대체로 증가한다고 보고한 바 있어 본 결과와는 차이를 보였다. 이는 어묵 제조시 사용되 는 부재료의 종류와 첨가량 모두 어묵의 질감에 큰 영향을 미치는 것으로 보고된 바 있어(37), 부재료 자체의 고유한 특성이 어묵의 물성에 영향을 미치는 것으로 생각된다. 이 상의 결과를 종합해 보면, 강황 분말의 첨가량이 증가할수 록 어묵의 경도, 응집성, 탄력성이 높아지는 경향을 나타낸 것을 알 수 있으며, 강황 분말의 첨가는 어묵의 조직감에 유의적으로 영향을 미치는 것을 확인할 수 있었다.

\section{강황 어묵의 관능검사}

강황 분말을 첨가한 어묵의 관능검사는 Table 5 와 같다. 어묵의 색도(color)의 경우, 색차계에 의해 측정한 색도는 강황 분말 첨가량이 높을수록 $\mathrm{L}$ 값과 $\mathrm{a}$ 값은 감소, $\mathrm{b}$ 값은 증가하는 경향을 보였는데 관능검사 결과에서는 $3 \%$ 와 $2 \%$ 의 강황 분말을 첨가한 군에서 높은 선호도를 나타내었다. 어묵의 향기(flavor)는 강황 분말 첨가량이 많을수록 선호도 가 높게 나타났다. 이는 강황의 향기 성분에 의한 생선냄새 의 masking에 의한 효과라 생각된다. 파래 첨가 어묵(12), 큰 느타리버섯을 첨가한 튀김 어묵(38) 및 양파 에탄올 추출 물 첨가 튀김 어묵(39)의 관능검사 결과에서도 색도와 향기 의 경우 비슷한 경향을 보였다. 어묵의 맛(taste)은 강황 분 말 $3 \%$ 첨가 어묵이 선호도가 가장 높았으며, 그 다음 $2 \%$ 첨가 어묵으로 대조군과는 유의차를 보였다. 복어 분말을 첨가한 어묵의 맛에 관한 연구에서는 대조군보다 복어 분말 첨가군의 선호도가 높게 나타났는데, 이는 복어에 다량 함 유된 taurine, hydroxyproline, lysine, glycine이 특징적인 맛 을 식품에 부여하기 때문인 것으로 보고하였다(11). Cho와 $\operatorname{Kim}(12)$ 은 파래 분말을 첨가한 어묵의 맛은 파래 분말 $5 \%$ 
첨가 어묵이 선호도가 가장 높았으며, 그 다음 $7 \%$ 첨가 어묵으로 대조군과는 유의차를 보였다고 보고한 바 있다. 강황 어묵의 조직감(texture)은 대조군과 강황 첨가 시료군 들 간에 차이를 나타내지 않았지만, $3 \%$ 첨가군을 선호하는 경향을 나타내어 강황 분말 첨가는 어묵의 식감을 향상시킬 수 있을 것으로 사료되었다. 전체적인 선호도(overall acceptance)는 강황 분말 첨가군들이 대체적으로 높게 나타 닜는데, $3 \%$ 첨가군이 가장 높은 선호도를 나타내었다. 이상 의 결과를 종합해 보면 강황 분말의 첨가는 전체적인 관능 평가에 긍정적인 영향을 미치며, 특히 강황 분말 $3 \%$ 첨가가 어묵의 기호도를 높일 수 있는 가장 적합한 농도로 사료된 다.

Table 5. Sensory evaluation of the fish paste samples containing different concentrations of Curcuma aromatica powder

\begin{tabular}{lcccc}
\hline \multicolumn{1}{c}{ Properties } & Control & $2 \mathrm{CAP}^{1)}$ & 3 CAP & 4 CAP \\
\hline Color & $3.22 \pm 0.10^{\mathrm{c}}$ & $3.44 \pm 0.12^{\mathrm{a}}$ & $3.52 \pm 0.21^{\mathrm{a} 2)}$ & $3.35 \pm 0.11^{\mathrm{b}}$ \\
Flavor & $2.66 \pm 0.04^{\mathrm{c}}$ & $2.96 \pm 0.11^{\mathrm{b}}$ & $3.44 \pm 0.25^{\mathrm{a}}$ & $3.36 \pm 0.21^{\mathrm{a}}$ \\
Taste & $3.10 \pm 1.12^{\mathrm{d}}$ & $3.24 \pm 1.00^{\mathrm{b}}$ & $3.42 \pm 1.11^{\mathrm{a}}$ & $3.17 \pm 1.02^{\mathrm{c}}$ \\
Texture & $3.65 \pm 1.21^{\mathrm{a}}$ & $3.64 \pm 1.13^{\mathrm{a}}$ & $3.88 \pm 1.25^{\mathrm{a}}$ & $3.56 \pm 1.05^{\mathrm{a}}$ \\
Overall acceptance & $3.40 \pm 0.11^{\mathrm{c}}$ & $3.66 \pm 0.25^{\mathrm{b}}$ & $3.90 \pm 0.32^{\mathrm{a}}$ & $3.47 \pm 0.21^{\mathrm{bc}}$ \\
\hline
\end{tabular}

${ }^{1)}$ Refer to the legend in Table 1 .

${ }^{2)}$ Values are mean \pm SD, different superscripts within a row(a-d) indicate significant different at $\mathrm{p}<0.05$.

\section{요 약}

강황 분말을 $0,2,3,4 \%$ 를 첨가한 어묵을 제조하여 색도, 절곡검사, 조직감, 관능검사 등의 품질 특성을 조사하였다. 색도 변화는 $\mathrm{L}, \mathrm{a}$ 값은 강황 분말의 첨가량이 증가할수록 감소하였고 $\mathrm{b}$ 값은 증가하였다. 어묵의 유연성과 탄력성을 나타내는 절 곡검사에서는 대조군을 포함한 모든 시료에서 $\mathrm{AA}$ 로 측정되어 강황 분말의 첨가에 관계없이 우수한 것으 로 나타났다. 강황 분말을 첨가한 어묵의 기계적 texture 특성은 강황 분말 첨가량이 증가할수록 경도(hardness), 응 집성(cohesiveness), 탄력성(springiness)은 증가하였고, 검 성 (gimminess)과 파쇄성(brittleness)은 감소하였다. 관능검 사 결과로 색깔(color), 향미(flavor), 조직감(texture), 맛 (taste), 전체적인 선호도(overall acceptance)는 $3 \%$ 의 첨가군 이 가장 높은 평가를 받았다. 따라서 강황 분말을 첨가한 기능성 강황 어묵의 가공 적성에 적절한 강황의 첨가량은 $3 \%$ 가 적당하다고 사료되며 강황을 함유한 고품질 어묵의 제조 가능성을 확인하였다.

\section{References}

1. Bae MS, Ha JU, Lee SC (2007) Quality properties of high calcium fish paste containing anchovy. Korean $\mathbf{J}$ Food Cookery Sci, 23, 561-566

2. Akahance Y, Shimizu Y (1990) Effects of setting incubation on the water-holding capacity of salt-ground fish meat and its heated gel. Nippon Suisan Gakkaishi, 56, 139-146

3. Chung KH, Lee CH (1996) Moisture-dependent gelation characteristics of nonfishprotein affect the surimi gel texture. Korean J Soc Food Sci, 12, 571-576

4. Lee NG, Yoo SG, Cho YJ (1999) Optimum rheological mixed ratio of jumbo squid and alaska pollock surimi for gel product process. J Korean Fish Soc, 32, 718-724

5. Yook HS, Lee JW, Lee HJ, Cha BS, Lee SY, Byun MW (2000) Quality properties of fish prepared with refined dietary fiber from ascidian (Halocynthia roretzi) tunic. J Korean Soc Food Sci Nutr, 29, 642-646

6. Park SM, Seo HK, Lee SC (2006) Preparation and quality properties of fish past containing styela plicata. Korean J Soc Food Sci Nutr, 35, 1256-1259

7. Kim JS, Byun GI (2009) Making fish paste with yam (Dioscorea japonica Thumb) powder and its characteristics. Korean J Culinary Research, 15, 57-69

8. Jang JA, Kim HA, Choi SK (2010) Quality characteristics of fish cake made with sliver pomfret (Pampus argenteus) with added wasabi powder. J East Asian Soc Dietary Life, 20, 103-112

9. Cho HS, Kim KH (2011) Quality characteristics of fish paste containing skate (Raja kenojeI) powder. J East Asian Soc Dietary Life, 21, 808-813

10. Seo JS, Cho HS (2012) Quality characteristics of fish paste with shrimp powder. Korean J Food Preserv, 19, 519-524

11. Park ID (2013) Quality characteristics of fish paste containing Lagocephalus lunaris powder. Korean J Food Culture, 28, 657-663

12. Cho HS, Kim KH (2014) Quality properties of fish paste containing green laver powder. Korean J Food Culture, 29, 421-427

13. Oh SW, Lee YC, Hong HD (2002) Effects on the shelf-life of tofu with ethanol extracts of Rubus coreancus Miquel, Therminalia Retz and Rhus javanica. Korean J Food Sci Technol, 34, 746-749

14. Hong JH (1996) Donguibogam. Poongensa, Seoul, p 1195

15. Lim DK, Choi U, Shin DH (1996) Antioxidative activity of ethanol extract from Korean medicinal plants. Korean J Food Sci Technol, 28, 83-89

16. Jayaprakasha GK, Jagan M, Rao L, Sakariah KK (2005) 
Chemistry and biological activities of $C$. longa. Trends Food Sci Technol, 16, 533-548

17. Park KN, Jeong EJ, Lee SH (2007) Antimicrobial activity of turmeric (Curcuma aromatica Salab.) extracts against various pathogens and spoilage bacteria isolated from tofu. Korean J Food Preserv, 14, 207-212

18. Park KN, Park LY, Kim DG, Park GS, Lee SH (2007) Effect of turmeric (Curcuma aromatica Salab.) on the shelf life of tofu. Korean J Food Preserv, 14, 136-141

19. Lim YS, Park KN, Lee SH (2007) Effects of tumeric (Cucuma aromatica Salab.) extract on shelf life of cooked rice. Korean J Food Preserv, 14, 445-450

20. Min YH, Kim JY, Park NY, Lee SH, Park GS (2007) Physicochemical quality characteristics of tofu prepared with turmeric (Curcuma aromatica Salab.). Korean J Food Cookery Sci, 23, 502-510

21. Park GS, Lee SH, Park KN (2007) The quality characteristics of Kanghwang (Curcuma aromatica Salab.) tofu prepared with various coagulants. J East Asian Soc Dietary Life, 17, 547-553

22. Kim JY, Park HS, Park NY, Lee SH, Park GS (2008) Quality characteristics of tofu stake with turmeric (Curcuma longa L.) J East Asian Soc Dietary Life, 17, 547-553

23. Lee HJ (2010) Preparation and properties of functional chocolate added with turmeric powder. MS Thesis, Kyonggi University, p 10-20

24. Yun EA, Jung EK, Joo NM (2013) Optimized processing of chicken sausage prepared with turmeric (Curcuma longa L.). Korean J Food Culture, 28, 204-211

25. Park BH, An SA, Cho HS (2014) Quality characteristics of Mandupi added with Curcuma aromatica powder. Korean J Food Culture, 29, 348-354

26. Kim SY, Son MH, Ha JU, Lee SC (2003) Presevation and characterization of fried surimi gel containing king oyster mushroom (Pleurotus eryngii). J Korean Soc Food Sci Nutr, 32, 855-858

27. AOAC (1990) Official Method of analysis 15th ed. Association of Official Analytical Chemists, Washington, DC, USA, p 8-35
28. Kang KH, No BS, Seo JH, Hu WD (1998) Food analysis. Sung Kyun Kwan University Academic press, Seoul, p 387-394

29. Kim KO, Kim SS, Sung NK, Lee YC (2000). Method and practice of sensory evaluation. Shinkang coolpansa, Seoul, p 58-97

30. Choi YS, Lee MH, Jhee OH (2011) Quality characteristics of sugar-snap cookies by addition of Curcuma longa L. powder. Korean J Culinary Res, 17, 198-208

31. Kang SK (2007) Changes in proximate composition, free amino acid, free sugar and vitamin of Curcuma longa L. and Curcuma atomatica Salib according to picking time. Korean J Food Preserv, 14, 624-632

32. Lanier TC, Lee CM (1992) Surimi technology. Marcel Dekker, New York, p 296-297

33. Choi SH, Kim SM (2012) Development of giant squid (Ommastrehes bartrami) surimi-based products with gel texture enhancers and the effects of setting on gel quality. J Korean Soc Food Sci Nutr, 41, 975-981

34. Shin YJ, Lee JA, Park GS (2008) Quality characteristics of fish paste containing Lycii fructus powder. Korean J Food Cookery Sci, 24, 690-699

35. Kim YY, Cho YJ (1992) Relationship between quality of frozen surimi and jelly strength of kamaboko. Bull Korean Fish Soc, 25, 73-78

36. Shin YJ, Park GS (2005) Quality characteristics of fish paste containing mulberry leaf powder. Korean J East Asian Soc Dietary Life, 15, 738-745

37. Kwon CS. Lee EH, Oh KS (1985) Effects of subsidiary materials on the texture of steamed alaska polack meat paste. Bull Korean Fish Soc, 18, 424-432

38. Kim SY, Son SH, Ha JU, Lee SC (2003) Preparation and characteristics of fried surimi gel containing king oyster mushroom (Plerotus-eryngii). J Korean Soc Food Nutr, 32, 855-858

39. Park YK, Kim HJ, Kim MH (2004) Quality characteristics of fried fish paste added with ethanol extract of onion. J Korean Soc Food Sci Nutr, 33, 1049-1055 